\title{
STUDIES ON THE HELMINTH FAUNA OF JAPAN -PART 56. CESTODES OF FISHES, III-
}

AUTHOR(S):

Yamaguti, Satyu

\section{CITATION:}

Yamaguti, Satyu. STUDIES ON THE HELMINTH FAUNA OF JAPAN -PART 56. CESTODES OF FISHES, III-. PUBLICATIONS OF THE SETO MARINE BIOLOGICAL LABORATORY 1960, 8(1): 41-50

ISSUE DATE:

1960-05-30

URL:

http://hdl.handle.net/2433/174704

RIGHT: 


\title{
STUDIES ON THE HELMINTH FAUNA OF JAPAN \\ PART 56. CESTODES OF FISHES, III ${ }^{12}$
}

\author{
SATYU YAMAGUTI \\ Zoological Institute, College of Science, Kyoto University
}

With Plates III-IV

CONTENTS

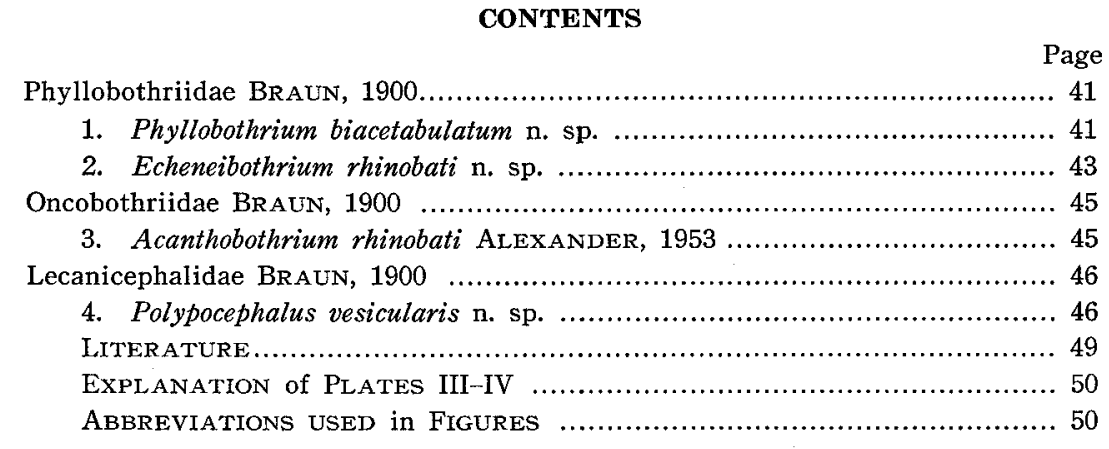

The four species described here were obtained from the spiral valve of a single specimen of Rhinobatus schlegeli Mueller et Henle, from the Inland Sea which died on October 9, 1959, in the aquarium of the Tamano Oceanographical Museum at Shibukawa, Okayama Prefecture. I wish to acknowledge my indebtedness to the authorities of the Museum for their help extended to me during my stay there.

PHYLLOBOTHRIIDAE BRAUN, 1900

\section{Phyllobothrium biacetabulatum n. sp.}

Material: A dozen mature specimens fixed under cover glass pressure in acetic sublimate alcohol and stained with Heidenhain's hematoxylin.

Total length $3.5-8.5 \mathrm{~mm}$. Scolex with four short-stalked, nearly circular bothridia about $0.3 \mathrm{~mm}$ in diameter; each bothridium with two fused acetabula,

1) Contributions from the Tamano Marine Laboratory, Okayama University, No. 66.

Publ. Seto Mar. Biol. Lab., VIII (1), 1960. (Article 3) 
one immediately behind the other, at its anterior end ; anterior acetabulum $60-75 \mu$, posterior $100-115 \mu$, in respective diameter; the acetabular lumen is continuous because the septum is a low ridge separating the lumen at the bottom alone; the wall of the acetabulum is $5-8 \mu$ thick and consists of muscle fibers set perpendicularly to the internal and external limiting membranes. The rest of the bothridial margin forms a circular frill divided into about 40 elongate loculi pressed against each other, the bothridial bottom being rather flat and not loculate. The frilled margin of the bothridium is sometimes flared and sometimes infolded, thus giving the bothridium a very variable appearance. Neck unsegmented, 0.1$0.15 \mathrm{~mm}$ long, followed by immature proglottides wider than long. Anlagen of gonads appearing at the 7 th segment in the type comprising 13 segments. The number of proglottides varies from 7 to 17 ; the mature proglottides are longer than wide, measuring $0.06-2.2 \times 0.15-0.4 \mathrm{~mm}$; this wide range of variation depends of course on the different degree of pressure applied on the cover glass; the habitual form is rather subcylindrical; the last segment of the type (Fig. 2) is somewhat disfigured, its width being exaggerated by cover glass pressure, and the anterior end appears constricted. Cuticle about $2 \mu$ thick, smooth.

Testes rounded, $18-30$ in number, $50-80 \times 55-130 \mu$, placed in one layer in intervascular medulla between anterior end of proglottis and level of genital pore. Vas deferens narrow, strongly convoluted between testes and ovary, intruding into space between ovarian wings of two sides. It enters the cirrus pouch through its anterior wall at a distance of $35 \mu$ from the distal end of the pouch which is $100 \mu$ long. Cirrus pouch ovoid to pyriform, thin-walled, $0.12 \times$ 0.043-0.1 mm; ejaculatory duct narrow, convoluted at base of cirrus pouch; cirrus unarmed, evaginable, swollen at its distal portion, surrounded by accompanying cells, opening into genital atrium immediately behind vagina. Genital atrium short cylindrical, $12-20 \mu$ wide; pores irregularly alternating, situated one-third to one-fourth the proglottis length from posterior end.

Ovary $\mathrm{H}$-shaped in dorsoventral view, but $\mathrm{X}$-shaped in lateral view, $0.26-0.5$ $\times 0.1-0.33 \mathrm{~mm}$ situated at posterior end of proglottis with some vitelline follicles on each side and behind. The germiduct arising from the oocapt on the ventral side of the ovarian isthmus proceeds forward a short distance and then backward to join in seminal duct, and after a short winding descending course enters the shell gland complex behind the ovarian isthmus, where it unites with the common vitelline duct coming down from near the oocapt. The uterine duct originating from the shell gland complex runs forward dorsal to the ovarian isthmus and describing an arcuate curve terminates blindly in the median line immediately behind the vagina at the level of the cirrus pouch; no eggs observed. Vitelline follicles extending in each lateral marginal area from near anterior end of proglottis to level of anterior end of ovary; some follicles, however, are seen lateral and posterior to the ovary; the paired vitelline ducts run transversely ventral to 
the ovarian isthmus and join together in close vicinity of the oocapt. The vagina opening into the genital atrium immediately in front of the cirrus runs inward transversely and then turning backward at right or wider angle descends windingly in the median field and crosses the ovarian isthmus dorsally along with the uterine duct; it is surrounded throughout its length by accompanying cells, its transverse distal portion lying ventral to the convoluted vas deferens is somewhat dilated and lined with heavily sclerotized cuticle. There is no seminal receptacle.

The ventral excretory stem passes lateral to the ovary ventral to the cirrus pouch and vagina and medial to the vitellaria; there seems to be no transverse anastomosis at the posterior end of each proglottis. The dorsal excretory stem is very narrow and sinuous, and lies approximately in the same sagittal plane as the ventral stem.

This species is characterized by the being provided at the front end with a bipartite acetabulum, hence the specific name.

\section{Echeneibothrium rhinobati n. sp.}

Material: A single mature specimen $6.35 \mathrm{~mm}$ long, fixed in acetic sublimate under slight cover glass pressure and stained with Heidenhain's hematoxylin.

Scolex with four pedunculate boat-shaped bothridia; each bothridium about $0.3 \mathrm{~mm}$ long, with blunt ends and two parallel rows of a number of shallow transverse areolae; the number of the areolae was unable to count; bothridial peduncle cylindrical, about $0.15 \mathrm{~mm}$ long by $0.05 \mathrm{~mm}$ broad. Neck $0.35 \mathrm{~mm}$ long, $0.09 \mathrm{~mm}$ broad at anterior end, slightly enlarged posteriorly, containing strong longitudinal muscle bundles, which are continued into the peduncles to be attached to the base of each bothridium. An indistinct segmentation commences as the strobila becomes moderately abruptly widened and granular, the first anlagen of the gonads making their appearance about $0.4 \mathrm{~mm}$ back of the neck. Immature proglottides wider than long, but mature ones are definitely longer than wide, 0.38 $0.75 \times 0.22-0.25 \mathrm{~mm}$, with convex sides, the last 29 th proglottis, detached during fixing manipulation, measuring $0.75 \mathrm{~mm}$ in length and $0.22 \mathrm{~mm}$ in maximum diameter at about middle. Cuticle smooth, about $3 \mu$ thick.

Testes 7-9 in number, usually $8,25-40 \times 30-60 \mu$, arranged in two, backwardly divergent rows in anterior part of proglottis; vas deferens up to $25 \mu$ wide, filled with spermatozoa, convoluted between posterior testes and anterior to vagina, which it crosses dorsally in the median line and extends further back of the cirrus pouch; finally it narrows considerably and enters the cirrus pouch through the anterior wall just distal to its middle. Cirrus pouch comparatively thinwalled, saccular, $0.12-0.15 \times 0.06-0.08 \mathrm{~mm}$, extending backward from genital atrium down to middle of proglottis. The ejaculatory duct enclosed in the cirrus pouch 
is narrow proximally but becomes widened and twisted distally and is provided with accompanying cells and followed by a strongly developed cirrus. The latter, lined with sharp-pointed teeth up to $7.5 \mu$ long by $5 \mu$ broad and covered with a dense coat of accompanying cells throughout its length, gradually widens toward its goblet-shaped terminal portion which is up to $60 \mu$ long by $50 \mu$ wide, well marked off from the rest and opens into the genital atrium immediately behind the vagina by a wide opening $20-30 \mu$ in diameter. Genital atrium $30-60 \mu$ wide, opening indifferently on right or left margin of proglottis at about one-third of proglottis length or a little more from anterior end.

Ovary V-shaped in dorsoventral view, $0.3-0.38 \times 0.15 \mathrm{~mm}$, extending just inside excretory stems from level of posterior end of cirrus pouch to near posterior end of proglottis, each lateral arm consisting of two (a dorsal and a ventral) irregularly outlined, longitudinal lobes. The germiduct arising from the oocapt proceeds forward a short distance and turns abruptly backward and unites with the seminal duct posterolateral to the oocapt, and then with the vitelline duct coming from behind; the shell gland complex surrounds the point where the fertilization canal turns back on itself to be continued into the uterine duct. The latter duct winds its way forward as a solid string of cells in the dorsal median field and reaches to near the posterior end of the cirrus pouch. Vitelline follicles of each side forming a narrow strand along entire lateral margin of proglottis outside of excretory stem and partly overlapping latter, without being interrupted on pore side at level of genital pore; the paired vitelline ducts coming from the posterior ends of the vitellaria unite with each other behind the base of the ovary; the common vitelline duct proceeds forward in the median field ventral to the ovary to join the fertilization canal. The vagina opening into the genital atrium immediately in front of the cirrus is very conspicuous owing to its wide distal portion being lined with thick cuticle and covered outside with a dense coat of accompanying cells; it extends transversely in front of the cirrus pouch from the genital atrium to the antiporal side of the cirrus pouch, forming an arch across the median line; then it narrows abruptly and runs backward in a sinuous course on the left side of the cirrus pouch, behind which it suddenly enlarges to form a wide tubular seminal receptacle; the latter narrows sooner or later and winds its way backward in the median field as a seminal duct which crosses the germiduct dorsally and turns back on itself just before joining the germiduct. The narrow winding dorsal and wide straight ventral excretory stems lie in the same sagittal plane between the vitellaria and the testes in the anterior part of the proglottis and between the vitellaria and the ovary in the posterior half of the proglottis with the terminal genitalia between; there is no transverse commissure for either stem.

Following Linton (1889), Euzet (1958) separated Rhinebothrium Linton from Echeneibothrium VAN BENEDEN on the ground that there is no myzorhynchus in 
Rhinebothrium, but, in Echeneibothrium minimum, type species of Echeneibohrtium by page precedence, the myzorhynchus is lacking, so that so far as the myzorhynchus is concerned there is no difference between Echeneibothrium and Rhinebothrium as pointed out by Southweld (1925, p. 207). On the contrary, those species with a distinct myzorhynchus should be separated from Echeneibothrium. In view of these considerations the present species belongs to Echeneibothrium, though it is to be assigned to Rhinebothrium according to Linton's scheme of classification supported by BEAR and EUzET. It differs from the most closely related Rhinebothrium walga (Shipley et Hoknell, 1905) of Euzet in number of testes and the distal portion of the vagina not being muscular at all.

\section{ONCOBOTHRIIDAE BRAUN, 1900}

\section{Acanthobothrium rhinobati ALEXANDER, 1953}

Material: A single mature specimen $10.5 \mathrm{~mm}$ long, fixed in acetic Schaudinn's solution under a cover glass, stained and mounted as usual.

Scolex about $0.5 \mathrm{~mm}$ long by $0.75 \mathrm{~mm}$ wide in flattened condition. Bothridia about $0.32 \mathrm{~mm}$ long, each divided into three loculi by two septa, the anterior loculus being the largest and the posterior the smallest, and surmounted by a single accessory sucker $0.27 \mathrm{~mm}$ wide; between the accessory sucker and the anterior loculus is a pair of bifurcated hooks, the total length of which is about $100 \mu$ long, both prongs being nearly equal in length (ca. 60 $\mu$ ); the inner prong bears a small tubercle at the base, and outer is bent at a wide angle. Neck nearly cylindrical, $20 \mathrm{~mm}$ long by $0.3 \mathrm{~mm}$ wide, covered with minute spines, containing numerous stout muscle bundles, of which four (two dorsal and two ventral) are conspicuous. Strobila serrate marginally; the total number of segments counted under a microscope is about 90 ; the anterior segments are, however, unable to count owing to their being two much crowded; as they proceed backward they increase in length, the last segment measuring $0.75 \mathrm{~mm}$ long by $0.55 \mathrm{~mm}$ wide, and the penultimate segment illustrated in Fig. $30.52 \times 0.63 \mathrm{~mm}$.

Cuticle smooth, very finely annulated, about $5 \mu$ thick. Internal longitudinal muscle layer directly enclosing vitellaria. Dorsal and ventral excretory stems winding in same sagittal plane between vitellaria and testes, with male and female terminal genital ducts between.

Testes oval, placed in one layer in intervascular medulla, confluent in median line at anterior end of proglottis, but separated by median vas deferens coils into two submedian groups, $19-30$ on pore side and $40-60$ on the other side, making a total of 59-90 for each proglottis. Vas deferens strongly convoluted in median field between two submedian groups of testes. Cirrus pouch $0.2 \times 0.07 \mathrm{~mm}$ in the penultimate segment, claviform, thin-walled, containing convoluted ductus ejaculatorius surrounded throughout by accompanying cells, extending oblique-trans- 
versely immediately in front of poral wing of ovary; cirrus heavily armed with minute spines. Genital atrium appears like direct continuation of the vagina. Genital pore equatorial, irregularly alternating.

Ovary consisting of four (two dorsal and two ventral) lateral wings just inside vitellaria and a transverse portion at posterior end of proglottis; poral ventral wing overlapping cirrus pouch ventrally. The germiduct arising from the oocapt describes an S-shaped curve before joining the vagina, and then turns back on itself to unite with the vitelline duct coming down on the ventral side of the ovarian isthmus. The wide uterine duct running forward sinuously over the dorsal side of the ovarian isthmus is unable to follow to its anterior end, the uterus proper is not yet developed. Vitelline follicles extending longitudinally lateral to excretory stems throughout proglottis length; in the ovarian region, they lie just outside the ovarian wings; vitelline ducts joining together ventral to oocapt. The vagina with a prominent sphincter just before opening into the genital atrium is divided into a wide distal portion running transversely anterior to the cirrus pouch and a narrower proximal portion winding in the median field; there is no seminal receptacle.

Although the present specimen does not completely agree with Alexander's description of Acanthobothrium rhinobati from Rhinobatus productus of Southern California waters, I prefer to assign it to this species for the present until additional material comes to hand.

\section{LECANICEPHALIDAE BRAUN, 1900}

\section{Polypocephalus vesicularis n. sp.}

Material: A single immature specimen with scolex, and eight fragments, gravid or mature, fixed in acetic sublimate alcohol under a cover glass, stained with Heidenhain's hematoxylin.

Total length unknown, probably more than $10 \mathrm{~mm}$. Type specimen with scolex, consisting of about 100 segments, $7.8 \mathrm{~mm}$ long; last immature segment quadrangular, $0.25 \times 0.32 \mathrm{~mm}$. Scolex globular, $0.28 \times 0.25 \mathrm{~mm}$; rostellum large, rounded, $0.2 \mathrm{~mm}$ in diameter, without central opening at apex, containing 14 hollow tentacular appendages, some of which are evaginated in form of smooth incurved digitiform processes up to $0.14 \mathrm{~mm}$ long by $25 \mu$ wide, the remaining are invaginated into the rostellum, each with a narrow centrol canal. These tentacles from a complete circle around the subapical border of the rostellum. Each of the 14 outer muscle bundles originating from the inner longitudinal musculature of the neck and running forward just outside of the rostellar sheath is continued at the base of each tentacle into the corresponding inner muscle bundle which is attached to the wall of the tentacular cavity at its blind end. So that this inner muscle bundle is seen running along the outer side of the wall of the 
tentacular cavity in the invaginated tentacle. Acetabulum weakly muscular, $50-60 \mu$ in diameter, situated one on each side and one dorsally and one ventrally at base of scolex. Neck $0.15 \mathrm{~mm}$ long by $0.17 \mathrm{~mm}$ wide. Strobila slightly craspedote, parallel-sided in immature and anterior mature proglottides, but constricted at intersegments in posterior mature and graved proglottides. Mature proglottides $0.35-0.5 \times 0.4-0.5 \mathrm{~mm}$, gravid ones elongate barrel-shaped, with salient posterior border, $0.9-1.25 \mathrm{~mm}$ in length, $0.5-0.58 \mathrm{~mm}$ in maximum width behind middle. Cuticle thin and smooth, very finely annulated transversely unless extended; subcuticlar longitudinal musculature and subcuticular cell layer well developed; no inner muscle sheath separating cortex from medulla.

In the immature proglottides the four transversely elongated elliptical testes, $0.15-0.2 \times 0.05-0.09 \mathrm{~mm}$, lie directly one behind another, occupying the whole intervascular parenchyma; in the mature proglottides they are oval to spherical and measure $0.06-0.12 \times 0.15-0.22 \mathrm{~mm}$, and the cirrus pouch containing swollen ejaculatory duct functioning as an internal seminal vesicle is oval, $0.15-0.2 \times$ 0.08-0.09 mm, often pushing the testes toward the antiporal side; the four-winged ovary lies at the posterior end of the proglottis, with a distinct seminal receptacle between its wings; 8-10 vitellarian acini extend in each lateral field; the wide sigmoid uterine duct provided with very fine longitudinal muscle fibers runs forward from the shell gland to the anteriormost testis across the vagina and cirrus pouch ventrally on the pore side.

In the gravid proglottides the four testes, $0.12-0.13 \times 0.16-0.22 \mathrm{~mm}$, are separated one from another dorsal to the uterus, the anteriormost lying directly anterior to the uterus. The vas deferens winding in front of the cirrus pouch enters the latter through its ventral wall near the middle. The pyriform cirrus pouch, $0.18-0.25 \times 0.1-0.13 \mathrm{~mm}$, is comparatively thin-walled, with numerous parenchymatous muscle cells attached to the base. The internal seminal vesicle vermiform, bent back on itself and occupying greater swollen part of the pouch giving the latter a vesicular appearance; its abruptly tapering, muscular, distal portion is well constricted off from the narrow cirrus which may be everted to the outside in form of an apparently smooth papilla $30 \mu$ in maximum width. Genital pore funnel-shaped, irregularly alternating, just pre-equatorial. The ovary is divided into four (two dorsal and two ventral) symmetrical lobes and a connecting isthmus from which the germiduct arises. There is no distinct oocapt. The germiduct joins the seminal duct near its own origin and then descends windingly to enter the shell gland complex, where it unites with the common vitelline duct coming down on the ventral side of the ovarian isthmus. The wide uterine duct originating from the shell gland complex proceeds obliquely forward on the right of the median line dorsal to the ovarian isthmus and passing on the right of the two posterior testes, crosses the cirrus pouch ventrally and then running along the anterior margin of the cirrus pouch turns forward to open into the uterus 
proper from the right side at the level of the second testis, being pressed against one of the right vitelline acini; it is provided with fine longitudinal muscle fibers throughout its length, attaining a maximum width of $0.08 \mathrm{~mm}$. When fully gravid the distended uterus proper is divided into five saccular compartments and extends in the ventral medulla from immediately behind the anteriormost testis to the ovarian isthmus, pushing the vitellaria and ovarian wings sideways and the three testes against the dorsal side, and widely notched in the region of the genital pore, where the genital pore and the adjoining vitelline follicles are left free. Eggs rounded, about $20 \mu$ in diameter as measured in situ on mounted specimen, each containing a segmenting ovum. No fully developed oncospheres have been observed. The vagina opening into the genital pore directly ventral to the cirrus proceeds backward and inward in a winding course dorsal to the uterus and enters the seminal receptacle behind the posteriormost testis; its distal portion is heavily cuticularized inside and provided outside with accompanying cells. The seminal receptacle is longitudinally elongated elliptical to pyriform, up to $0.16 \times 0.1 \mathrm{~mm}$, lies dorsal to the uterus behind the posteriormost testis, slightly to the pore side of the median line, with its broader end in front. The narrow seminal duct arising from the posterior end of the seminal receptacle descends a little obliquely dorsal to the uterus, along the posterior end of which it turns ventrad to join the germiduct. The large vitelline follicles, 10-14 on each side and pressed by the gravid uterus against the lateral margins of the proglottis, extend from the level between the anterior two testes to the anterior end of the ovarian wings, with two follicles behind the ovary on each side; the paired transverse vitelline ducts unite together in the median line ventral to the ovarian isthmus, the short common vitelline duct descending from this junction enters the shell gland complex to unite with the fertilization canal. The shell gland forms a compact median mass behind the ovarian isthmus between the posterior ovarian lobes.

The dorsal and ventral excretory stems run windingly inside the vitellaria, the dorsal being a little medial to the ventral. The two stems are very conspicuous in the immature proglottides, in which the dorsal stem passes between the ventral vagina and the dorsal cirrus pouch, and the ventral stem ventral to the distal end of the cirrus pouch. There is a distinct transverse anastomosis between the ventral stems at the posterior end of the proglottis.

Of the nine species of Polypocephalus listed in my "System Helminthum" Vol. II only $P$. rhinobatidis SubhapradHa, 1951 and $P$. affinis Subhapradha, 1951 have six testes, all the others except $P$. sulcher (ShIPLEy et Hornell, 1906) ${ }^{12}$ possessing four testes. The present species resembles $P$. lintoni SubHapradHa, 1951 most closely, especially in the anatomy of the genital organs, but differs from it in size of gravid proglottides, and cirrus pouch as shown in the following table.

1) ShIPlEy and HoRNell made no mention. 


\begin{tabular}{lll} 
& \multicolumn{1}{c}{$P$. lintoni } & \multicolumn{1}{c}{ Present species } \\
Gravid proglottides & $0.606 \times 0.277$ & $0.9-1.25 \times 0.5-0.58$ \\
Cirrus pouch & $0.135 \times 0.038$ & $0.18-0.25 \times 0.1-0.13$ \\
Host & Rhynchobatus djeddensis & Rhinobatus schlegeli
\end{tabular}

In her Fig. 20 of $P$. lintoni Subhapradha illustrates the vas deferens (v.d.) as originating from near the ovarian isthmus as in Fig. 6 of $P$. rhinobatidis, Fig. 15 of $P$. radiatus, Fig. 22 of $P$. medusia, Fig. 28 of $P$. rhynchobatidis, but in my observation of the present species this duct corresponds to the uterine duct, and the uterine duct, and the uterus proper connected with this duct develops later. SubHapradHa does not mention the presence of a seminal receptacle in $P$. lintoni, but in our species it is clearly seen behind the posteriormost testis. Further she states that in $P$. lintoni the ventral and dorsal surface are interchangeable. This, however, has never been observed in the species under consideration.

The specific name refers to the vesicular appearance of the cirrus pouch.

\section{LITERATURE}

Alexander, C. G. 1953. Five new species of Acanthobothrium (Cestoda: Tetraphyllidea) from Southern California rays. J. Parasit. 39 (5), 481-486.

Euzet, L. 1956. Recherches sur les cestodes Tetraphyllides selaciens des cotes de France. Thèse, Universite Montpellier. $263 \mathrm{pp}$.

Linton, E. 1889. Notes on Entozoa of marine fishes of New England. Rep. U. S. Comm. Fish $\&$ Fisheries for $1886,435-511$.

SOUTHWELL, T. 1925. A monograph on the Tetraphyllidea with notes on related cestodes. Liverpool School of Trop. Med. Memoir, N. S., No. 2, 368 pp.

Subhapradha, C. K. 1951. On the genus Polypocephalus Braun, 1878 (Cestoda), together with descriptions of six new species from Madras. Proc. Zool. Soc. London, 121, Part II, 205-235.

YamaGuTI, S. 1959. Systema Helminthum. Vol. II. The cestodes of vertebrates. Interscience, New York, London. 860 pp. 


\section{EXPLANATION OF PLATES III-IV}

\section{Plate III}

Fig. 1. Scolex of Phyllobothrium biacetabulatum n. sp.

Fig. 2. Mature proglottis of Phyllobothrium biacetabulatum n. sp.

Fig. 3. Mature proglottides of Acanthobothrium rhinobati Alexander, 1953.

Fig. 4. Anterior extremity of Acanthobothrium rhinobati Alexander, 1953.

\section{Plate IV}

Fig. 5. Anterior extremity of Echeneibothrium rhinobati n. sp.

Fig. 6. Mature proglottis of Echeneibothrium rhinobati n. sp.

Fig. 7. Anterior extremity of Polypocephalus vesicularis. n. sp.

Fig. 8. Mature proglottis of Polypocephalus vesicularis n. sp.

\section{ABBREVIATIONS USED IN FIGURES}

$a=$ acetabulum, $c=$ cirrus, $c p=$ cirrus pouch, $g p=$ genital pore, $o=$ ovary, $r s=$ receptaculum seminis, $s g=$ shell gland, $t=$ testis, $t a=$ tentacular appendage, $u d=$ uterine duct, $v d=$ vas deferens, $v g=$ vagina, $v t=$ vitellarium. 
Publ. Seto Mar. Biol. Lab., VIII, 1 (1960)
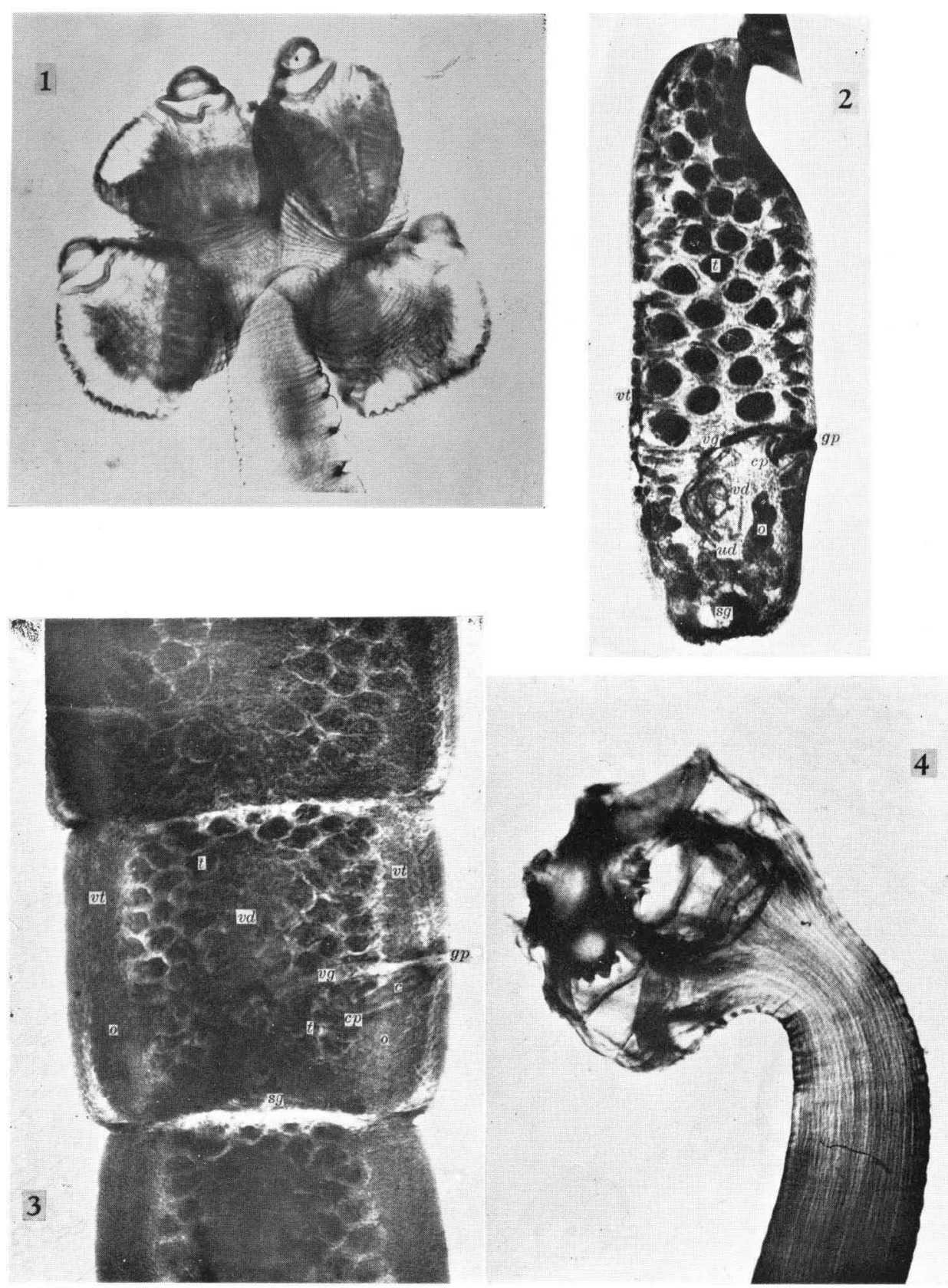

S. Yamaguti: Studies on the Helminth Fauna of Japan, 56. 
Publ. Seto Mar. Biol. Lab., VIII, 1 (1960)

PLATE IV
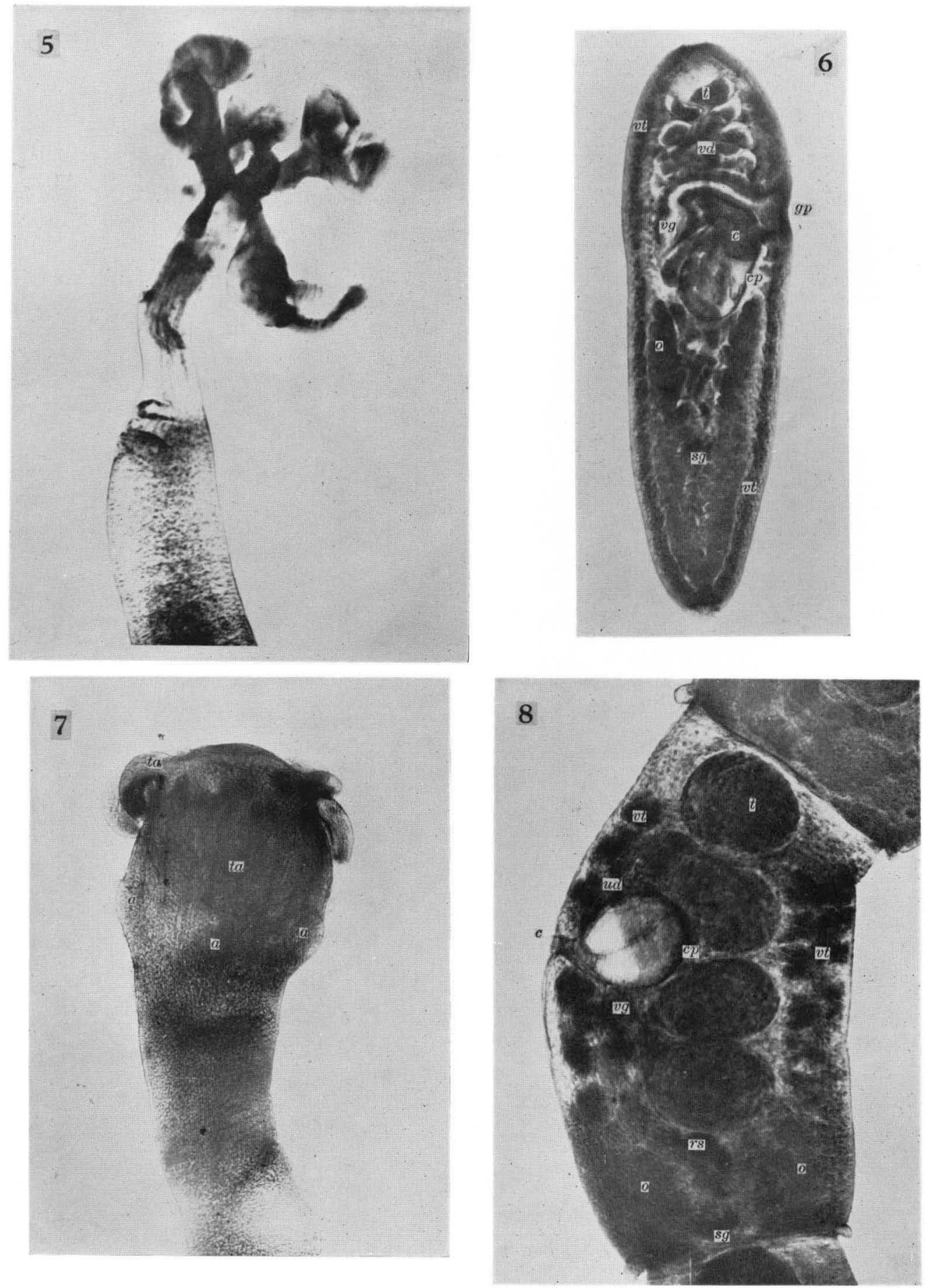

S. Yamaguti: Studies on the Helminth Fauna of Japan, 56. 